Revista de la red interuniversitaria de estudios sobre las literaturas rioplatenses contemporáneas en Francia

15 | 2016

Un año. Literatura argentina 1969

\title{
1889: Por qué y cómo escribí este libro -y algunos otros
}

\section{Marc Angenot}

Traductor: Natalia Plaza Morales y Revisada por Cecilia González y Carlos Walker

\section{OpenEdition}

\section{Journals}

Edición electrónica

URL: https://journals.openedition.org/lirico/3176

DOI: $10.4000 /$ lirico.3176

ISSN: 2262-8339

Editor

Réseau interuniversitaire d'étude des littératures contemporaines du Río de la Plata

\section{Referencia electrónica}

Marc Angenot, «1889: Por qué y cómo escribí este libro -y algunos otros», Cuadernos LIRICO [En línea], 15 | 2016, Publicado el 05 octubre 2016, consultado el 21 septiembre 2021. URL: http:// journals.openedition.org/lirico/3176 ; DOl: https://doi.org/10.4000/lirico.3176

Este documento fue generado automáticamente el 21 septiembre 2021.

\section{c)}

Cuadernos LIRICO está distribuido bajo una Licencia Creative Commons Atribución-NoComercialSinDerivar 4.0 Internacional. 


\title{
1889: Por qué y cómo escribí este libro - $y$ algunos otros
}

\author{
Marc Angenot \\ Tradución : Natalia Plaza Morales y Revisada por Cecilia González y Carlos Walker
}

\section{NOTA DEL EDITOR}

En nombre de Cuadernos LIRICO agradecemos el acuerdo del autor para publicar esta traducción. El original en francés fue publicado en 2013 y se encuentra disponible en línea: http://www.medias19.org/index.php?id=13856\#bodyftn18. El mismo sitio ofrece un acceso abierto al libro completo de Marc Angenot, 1889, un état du discours social. Las notas de traducción se incluyen entre corchetes.

À bien réfléchir, ce ne sont pas les individus qui pensent, ce sont les sociétés : ce ne sont pas les hommes qui inventent, ce sont les siècles.

Louis Blanc, Questions d'aujourd'hui et de demain, París: Dentu 1873, V, p. 400.

\section{Retorno sobre un recorrido de investigación}

2 En 1967 defendí un doctorado en filosofía y letras en la Universidad libre de Bruselas con una tesis principal sobre la Retórica del surrealismo y una tesis anexa sobre el criollo haitiano. Mis tesis habían sido dirigidas por el filólogo y estilista Albert Henry (1910-2002), de quien conservo un grato recuerdo: fue él quien me procuró inesperadamente un lugar en el FNRS, el Fondo Nacional belga para la Investigación Científica (antes había apreciado mi modesta memoria de licenciatura sobre Stèles de Victor Segalen), lo que me significó una beca de tres años y me permitió hacer esta tesis. Seguramente, no habría podido terminarla de otra forma. Entre mis profesores, mencionaré -entre otros por los que guardo un recuerdo lleno de respeto (es, según 
dicen, un sentimiento que se pierde)- al filósofo de la nouvelle rhétorique, Chaïm Perelman (1912-1984), a Roland Mortier, gran especialista del siglo XVIII (1920-), y al pionero de la sociología de la literatura que impartía un seminario en el Instituto de sociología, Lucien Goldmann (1913-1970).

Cuando estaba terminando la tesis me puse a buscar un lugar para continuar. En Bélgica, poco antes de la repentina y rápida expansión del viejo sistema universitario "elitista", cuyo crecimiento iba a permitir la entrada masiva de la generación de baby-boomers en la nueva universidad de masas que se puso en marcha en menos de una década, la perspectiva estándar para la carrera de un joven doctor era pasar muchos años en un liceo de provincia antes de ser contratado algún día, con suerte y algunos "contactos", como profesor asistente, y tal vez, pasada la cuarentena, como "profesor extraordinario". En los pasillos me fijé en algunos carteles que anunciaban puestos en el extranjero: si mal no recuerdo, en Oran, en Lubumbashi y en Montreal. Descarté los dos primeros y me dije vamos por Montreal, podría pasar allí algunos años.

Desde el año 1967 soy profesor en la universidad McGill, en el Departamento de lengua y literatura francesas ${ }^{1}$, y desde 2013 "profesor emérito", cuyo promoción recibí con cierta ambivalencia, a pesar de las felicitaciones rectorales y del recorrido que la acompañan. Hace más de cuarenta años -tenía veinticinco y "es como si fuese ayer"- aterricé en el aeropuerto de Dorval con un bebé bajo el brazo (mi hijo Olivier) y un contrato de profesor adjunto en McGill. Es una gracia que la vida me ha dado y creo haber sacado de ella todo el provecho posible. Así fue como me puse a trabajar. Desde entonces quiero a este país que se ha vuelto el mío, tal y como la labor de profesor -y nunca he mirado atrás (actitud que no fue lograda, como sabemos, por la mujer de Lot).

Mis primeros libros se ocuparon de los márgenes de la literatura canónica y de los sectores desatendidos por la tradición universitaria. No sabía mucho qué esperaba de la vida -en particular de la vida intelectual, pues no estaba seguro de manejar las reglas del juego universitario-, pero tenía curiosidad: la hierba me parecía más verde del otro lado del cerco académico. Una empresa de este tipo, realizada por fuera de los senderos triunfales del canon literario y de los métodos dominantes, no parecía ni un poco prometedora para "la carrera" en los Viejos países, -incluso parecía un poco suicida. Pero no tenía mucho de qué preocuparme: en el Quebec de la Revolución tranquila todo estaba por hacerse. La dinámica de esos años fue impresionante, partiendo de un indiscutible subdesarrollo y de un sentimiento de urgencia por corregirlo, la vigilancia oficial sobre el académico no era tan fastidiosa como en otros lugares. Todo parecía posible, siempre y cuando no se incurriera en riesgos mayores (a pesar que mis intereses exasperaban a unos cuantos viejos y no tan viejos colegas que me lo hicieron sentir).

Le roman populaire: recherches en paralittérature (Montreal: PUQ, 1975) aborda los temas y los géneros de la novela-folletín [roman-feuilleton] del siglo XIX, entre Les Mystères de Paris y Fantômas. Había obtenido de Ottawa una primera subvención de investigación trianual para elaborar este trabajo y para adquirir una colección de novelas a "65 céntimos" de Fayard, Ferenczi, Tallandier, Rouff, aparecidas antes de 1914 (subvención que entonces la otorgaba el único Consejo de las artes de Canadá, antes de la creación del $\mathrm{CRSH}^{2}$ y de su posterior competidor, el FCAR quebequés). Fue en la postguerra, hacia 1960, que algunos ojos académicos se abrieron al simple hecho de la existencia masiva de una producción impresa excluida del canon de las bellas letras, iniciando, de un modo dubitativo, una puesta en consideración crítica de las literaturas "obrera" o "popular", de lo impreso que hacía parte de la "cultura de masas", de la "infraliteratura", de la 
"paraliteratura", de la Kulturindustrie, la Trivialliteratur ${ }^{3}$. Los estudios literarios son el único dominio académico, el único ámbito de las llamadas "ciencias humanas" que comienza descartando el noventa por ciento y más de lo que puede parecer su objeto "natural", sin por ello ofrecer un motivo ni preguntarse por este perjudicial descarte. A lo largo de los dos siglos modernos, la abrumadora mayoría de lo publicado como "novelas" -aunque más no sea por el mero hecho de designarse así en la página del título-, ha sido excluida de toda consideración, tal y como sucede con el conjunto de textos versificados. Todo ello, incluso antes de ser considerados y bien a pesar de que unos y otros hayan recibido la sanción de lo impreso y de que sea posible verificar su difusión. Lo mismo ocurre para una porción aún más masiva, desde el texto dramático de Pixerécourt hasta el teatro de boulevard.

En esta misma época publiqué varios estudios sobre la utopía y las primeras obras de ciencia ficción francesas, y entre 1978 y 1984 fundé y dirigí Science-Fiction Studies, junto con R. D. Mullen y mi amigo comparatista Darko Suvin, cuya publicación fue y sigue siendo, la única revista "erudita" en este ámbito.

Desde ese entonces trabajé, en paralelo, sobre la revitalización de la antigua retórica en el marco de los nuevos métodos de análisis semióticos hacia los cuales me llevaba la formación "filológica" típica de la enseñanza universitaria belga (sólo había participado en dos cursos "obligatorios" de Ch. Perelman y no en este ámbito, aunque este género de cosas me interesaban, anda a saber por qué, y además conocía un poco su Traitét). La parole pamhlétaire, obra publicada por Payot en 1982 y regularmente reeditada, constituyó, se ha escrito -y ello no deja de alborozarme- "un hito" dentro los desatendidos análisis de polémicas y de la "literatura de ideas".

9 Por su parte, Les Champions des femmes (Montreal, PUQ, 1977) examina una larga tradición erudita y galante que, entre 1400 y 1800 , pretendió demostrar con numerosos ejemplos y pruebas tópicas la superioridad del sexo femenino.

10 La retórica de la argumentación, según pensaba, no debía ser más que un elemento dentro de una disciplina emergente y dubitativa, pero que me seducía; mientras que los estudios de letras me parecían a menudo estériles, parasitarios, vanos y aburridos, a pesar de que allí encontré la disciplina a la que me iba a consagrar: el análisis del discurso. Dicha disciplina parte de una idea simple: "lo que se dice y se escribe en la vida en sociedad no es jamás aleatorio ni "inocente"; una disputa de pareja tiene sus reglas y sus roles, su tópica, su retórica, su pragmática, y esas reglas no son las mismas para un mandato episcopal, un editorial político o la profesión de fe de un candidato a diputado. Este tipo de reglas no derivan del código lingüístico. Ellas forman un objeto particular, plenamente autónomo, esencial para el estudio del hombre en sociedad. Este objeto, sociológico y por lo tanto histórico, es la manera en que las sociedades se conocen al hablarse y al escribirse, donde el hombre-en-sociedad se narra y se argumenta.

11 A fines de los setenta me encontré con Régine Robine, historiadora de la revolución francesa que había contribuido a fundar lo que conocemos como la "Escuela francesa de análisis del discurso". Régine, inmigrante en Canadá, fue otra de mis suertes, una "gracia" de la vida, pues la probabilidad de trabajar con alguien que, por vías distintas a las mías (puesto que ella era historiadora), se interesase activamente en el análisis del discurso eran escasas. En 1974, un poco por casualidad y en medio de un divorcio, Robine vino a pasar varios meses como profesora invitada de la UQAM. A partir de entonces volvió regularmente. Después de algunos años entre los dos continentes, se estableció en Canadá definitivamente en 1978 y fue contratada en sociología en la UQAM. Nos hicimos amigos y 
hemos colaborado más de una vez en proyectos de investigación. Su Histoire et linguistique, editada por Colin en 1973, fue una obra pionera, una obra que abría un campo nuevo, una nueva problemática ${ }^{5}$. Se trató de un encuentro inesperado entre dos saberes incompletos: una ciencia que olvida la historia (tal y como lo decía Bourdieu acerca de la lingüística) y una historia que olvida que sus archivos están hechos de palabras y de enunciados opacos y que nada es más histórico que aquello que las sociedades se dicen a ellas mismas.

caso, mis primeros ensayos en este dominio datan de principios de 1980. Son ajenos a los estudios literarios, tal y como entonces se delimitaban, son ensayos cercanos a la historia de las ideas (categoría poco reconocida y mal identificada). Me refiero, por ejemplo, a "Malaise dans l'idée de progrès" en Mots: les langages du politique ( $\mathrm{n}^{\circ} 19$, junio 1989); "Savoir et autorité: le discours de l'anthropologie préhistorique" en Littérature ( ${ }^{\circ}$ 50, 1983); y del mismo año, una "Lecture intertextuelle d'un texte de Freud", en la revista Poétique ( $\left.{ }^{\circ} 56\right)$.

En abril de 1981 nació mi hija Maya ${ }^{6}$, y Nadia Khouri, mi mujer, defendió su tesis en otoño de ese mismo año en la Universidad McGill: The Other Side of Otherness, sobre las utopías americanas del siglo XIX. Recuerdo que un día de primavera de aquel año se me metió en la cabeza elaborar una teoría del "discurso social" y, una mañana en mi despacho del Programa de literatura comparada en la calle Peel, en un estado de trance, de "dictado automático", sin tener consciencia al menos de haber reflexionado mucho al respecto con anterioridad, desarrollé en algunas páginas el esbozo de una teoría y un proyecto para su aplicación en un vasto corpus de corte sincrónico que decidí sobre la marcha. Estas son cosas que pasan.

La crítica del discurso social iba a aprehender y analizar en totalidad la representación discursiva del mundo, tal y como se expresa en un estado de sociedad, cuya producción presupone el sistema completo de "intereses" de los cuales una sociedad se ocupa. Se trataba para mí de construir una problemática y una batería de conceptos susceptibles de dar razón a la totalidad de lo escrito, lo impreso y lo difundido en un momento dado de la sociedad. Buscaba considerar en su totalidad el inmenso rumor de aquello que se dice y se escribe, abarcando todos los sectores, todas las disciplinas, todos los "campos" discursivos. Quería dar una consistencia teórica a un objeto intuitivo, la "cultura" de una época, el Zeitgeist, el espíritu del tiempo en su singularidad.

La elaboración de mi teoría se apoyó sobre un inmenso campo de investigación, el análisis sistemático de la cosa impresa producida por la lengua francesa en el curso de un año que había elegido con algunas buenas razones contingentes: el año 1889. ¿Por qué? Mil ochocientos ochenta y nueve es simplemente un año "rico" y un año bisagra: es al mismo tiempo el año del centenario de la Revolución, el año de la Exposición universal, de la Torre Eiffel, el año de la resistible ascensión y caída del bravo general Boulanger, el año del "Drama de Meyerling"' y de algunos otros acontecimientos importantes. De todas formas, me movía a ciegas; no era de ninguna manera un experto decimonónico y tenía todo por aprender.

16 Pedí y obtuve una subvención trianual del CRSH, que me fue renovada y que me permitió dedicar siete años a "examinar" el asunto. Trabajo "bulímico", me dijeron, sería difícil negarlo: no solamente examiné en detalle, también sistematicé un método de trabajo concienzudo que me pareció al fin y al cabo no haber dejado en la sombra ningún tipo de soporte impreso por analizar, a saber: 1207 libros y folletos, el conjunto de los grandes periódicos de París, sondeos en otros periódicos parisinos de menor importancia (que llegan hasta 157), una decena de folletos regionales (de Lille, Lyon y Marsella ${ }^{8}$ ), 487 
periódicos de todo tipo, yendo desde la Revue des Deux Mondes hasta el folleto de estación balneario, pasando por las pequeñas revistas de vanguardia literaria y por "todas las publicaciones bien establecidas de las diferentes disciplinas científicas y tendencias filosóficas", así como por las canciones de café-concert, los afiches comerciales y administrativos, las imágenes de Épinal, los catálogos de las grandes tiendas, etc. En ese entonces frecuenté asiduamente todas las bibliotecas de Montreal, la de la Universidad de Toronto, donde está el notable y poco frecuentado Centro Sablé, la Biblioteca real en Bruselas, y en París la BN, aún en la calle Richelieu, el Arsenal, los Archivos nacionales -y más tarde, en mis investigaciones sobre la historia del movimiento obrero, añadí a mis peregrinaciones parisinas la biblioteca del CEDIAS-Museo social, en la calle Les Cases, y los archivos de la Prefectura de policía en el quinto distrito.

De este proyecto de análisis global en corte sincrónico salió un libro de mil doscientas páginas, Mil huit cent quatre-vingt-neuf: un état du discours social (Le Préambule, 1989) ${ }^{9}$. En el "mercado discursivo" de una época hay sin duda objetos temáticos y formaciones discursivas infinitamente diversas por su estatus social, su régimen cognitivo, sus destinatarios. Están los lugares comunes de la conversación, las grandes bromas del Café del comercio, las canciones del café-concert, los espacios esotéricos (ellos mismos estratificados en término de grados de "distinción") del periodismo y los doxógrafos de "la opinión pública" y de la "actualidad", así como las formas etéreas y prestigiosas (e incluso esotéricas e inaccesibles a lo común) de la investigación estética, de la especulación filosófica, de la formalización científica. También están las doctrinas políticas y sociales establecidas que se enfrentan ruidosamente, y los murmullos periféricos de grupúsculos y de espíritus disidentes. Todos estos lugares del discurso están provistos en un momento dado de aceptabilidad y de "encantos", tienen públicos cautivos, cuyos hábitos adquiridos comportan una sensibilidad a sus influencias, una capacidad de disfrutarlos y de renovar su necesidad, ya sea que este gusto se incline (por hablar de hoy) por los folletines sentimentales [romans-savons] o por la ficción postmoderna, ya sea que encuentre su alimento cotidiano en Le Parisien o en Le Monde.

18 A primera vista, el vasto rumor de los discursos sociales da la impresión del caos originario [tohu-bohu], de la cacofonía, de una extrema diversidad de géneros, de temas, de opiniones, de lenguajes, de jergas y de estilos; es en esta multiplicidad, en esta "heteroglosia" o "heterologia" sobre la que el pensamiento de Mikhail M. Bakhtine, discutido en ese entonces con pasión, parecía sobre todo haberse detenido. Más allá de esta cacofonía aparente, mi procedimiento consistió en buscar las invariantes, los presupuestos, los "lugares comunes" (usemos de manera apropiada la palabra de Aristóteles), los dominantes y las recurrencias, lo regulado, los principios de cohesión, las restricciones y las coalescencias que hacen que el discurso social no sea una yuxtaposición de "formaciones discursivas" autónomas, sino un espacio de interacciones donde las imposiciones de temas y de "maneras de ver" aportan al Zeitgeist una especie de co-inteligibilidad "orgánica" y fijan los límites de lo argumentable, de lo narrable, de lo escribible y de lo pensable.

19 El objeto que busqué describir y sintetizar no era, de hecho, el todo empírico de la superficie, cacofónico y redundante, se trataba más bien de las reglas de producción y de organización de los enunciados, las tipologías y topografías, los repertorios tópicos y los presupuestos cognitivos, los principios de "división del trabajo" discursivo que, para una sociedad dada, organizan y delimitan lo pensable, lo narrable y lo argumentable; si proponemos que narrar y argumentar son los dos modos predominantes del discurso. 
Empecé entonces de lo "fenoménico", de una masa abigarrada y difícil de dominar de textos de "todos los géneros", para buscar identificar los principios de engendramiento, las reglas subyacentes, los esquemas de base. Mi trabajo consistió en sentir y localizar el eterno retorno de lo mismo (das Immerwiedergleich, como dice Walter Benjamin de las noticias misceláneas) y en extrapolar los "repertorios" tópicos donde van a abastecerse los escribientes de todos los sectores; en hacer resurgir a la vez las tendencias generales y los avatares locales de las formas y temas fundamentales, el rumor de una "base continua" detrás de las variaciones de una serie de "motivos", la permanencia de la doxa en la sorpresa de reformulaciones y paradojas, el retorno de ciertos paradigmas, presuposiciones y constantes en las apropiaciones divergentes, en los desacuerdos aparentes y en las individuaciones, en las producciones que una época acoge como "originales"; en otros términos, la presencia de "leyes" tácitas y de tendencias colectivas en las idiosincrasias de "opiniones individuales" y de innovaciones estéticas que encubren banalmente los mercados de producción simbólica.

Es así que para nosotros, con eso que llamamos "el repliegue del tiempo", la psicopatología de la histeria según Charcot, la literatura boulevardière y libertina de Catulle Mendès, el espíritu de Henri Rochefort y el de Aurelien Scholl, las novelas de Emile Zola y las de Paul Bourget, los panfletos antisemitas de Édouard Drumont y las canciones de café-concert de Paulus nos parecen intuitivamente, tanto por su forma como por su contenido, pertenecer a la misma época -esa época que los contemporáneos habían llamado, con un matiz de angustia crepuscular, el "Fin de siècle", y que una generación más tarde, después de 1914, se la identificará con nostalgia como "La Belle Époque", que va grosso modo desde la presidencia de Sadi Carnot a la de Félix Faure.

La noción de sincronía, cuyo sentido me interrogaba para otorgarle razón a un estado del discurso social, era evidentemente opuesta a la de la lingüística estructural. La sincronía saussureana es una construcción ideo-típica que forma un sistema homeostático de unidades funcionales. La sincronía de la que hablaba forma una contemporaneidad en tiempo real. Si existe en todo momento, tal y como formulo como hipótesis, una cierta regulación "sistémica" (con comillas) del discurso social, una división del trabajo, división reglada de los campos y de los géneros discursivos con sus decibles propios, el estudio sincrónico hace también aparecer puntos de unión, de conflictos, de formaciones "ideológicas" emergentes y de otros recesivos, de lo arcaico y de lo nuevo y, sobre la escala de las "distinciones", da a ver lo dóxico trivial y la paradoja distinguida, lo innovador superficial y las antinomias profundas -y fugazmente, lo "inaudito". Un estado de cultura no es entonces un "sistema", sino una homeostasis relativa con fluctuaciones y conflictos. Desprende sin embargo una "atmósfera" engendrada por una vasta aglomeración de creencias más o menos co-inteligibles, de lugares, presupuestos, ideas recibidas, estereotipos, valores, mitos, el todo regulado por los presupuestos fundamentales. La coherencia relativa de todo esto deriva de un bricolaje regido por el "sentido común" prevaleciente. El discurso social forma cuanto menos un "mercado" sometido a tendencias generales, un mercado cuyos sectores en interacción son permeables los unos con los otros y en el cual los regímenes locales de producción de sentido se explican en parte por esta interacción y por los posicionamientos topográficos respectivos. Al renunciar al análisis sectorial aislado de géneros y de campos discursivos determinados -literario, filosófico, científico, político, periodístico- mi análisis pretendía sortear las divisiones de la investigación, integrar los "sectores" discursivos particulares en una red interdiscursiva global, hacer frente a la enorme masa cacofónica de lenguajes 
que llegan al oído del hombre-en-sociedad y reconquistar así una perspectiva totalizadora. El investigador iba a poder identificar las recurrencias y los dominantes, las maneras de conocer y de significar lo conocido que son propias de ese estado de sociedad, y que transcienden la división de los discursos.

Para designar esas constantes, esas recurrencias y esas reglas de lo escribible, he utilizado el término de hegemonía. No llamo "hegemonía" a los esquemas discursivos, temas, ideas que prevalecen, que tienen el más alto nivel de legitimidad en un momento dado. La hegemonía tampoco es la dominación cuantitativa, la cual haría a fines del siglo XIX más "audibles" los clichés del café-concert y la gran broma de las revistas populares que los sutiles debates de la Revue des Deux Mondes. La hegemonía es un conjunto de mecanismos reguladores que arbitran a la vez la división del trabajo discursivo y sus jerarquías, todo ello asegurando un grado de homogenización de la retórica, de la doxa y de los tópicos interdiscursivos. Estos mecanismos se imponen sobre lo que se dice y lo que se escribe de la aceptabilidad y estratifican los grados y las marcas de legitimización y de distinción. La hegemonía se compone entonces de reglas canónicas de géneros y de discursos (incluido sus márgenes de variación y desviación aceptables), de preeminencias y de estatus de los diferentes discursos que le son propios, de las normas del buen lenguaje (incluido el control de grados de distinción del lenguaje, del alto estilo literario al todo vale de la escritura periodística "de conventillo" como le decían los letrados), de las formas aceptables de la narración, de la argumentación, y, de manera más general, de la cognición discursiva y del repertorio de temas que se le "imponen" a todos, pero de tal forma que su tratamiento abra el campo de debates y de disensiones ellas mismas reguladas por convenciones de forma y de contenido. Si la hegemonía está formada de regularidades que hacen aceptable y eficaz lo dicho, que confieren un estatus determinado a lo que se dice, ella aparece como un sistema que se regula a sí mismo sin que haya detrás un jefe de orquesta, un deus in machina, un puesto de comando panóptico, ni siquiera una serie de relevos provistos de una identidad y de un rostro.

Por otra parte, el efecto de "masa sincrónica" del discurso social sobredetermina la legibilidad (el modo adecuado de lectura y de interpretación) de los textos particulares que forman esta masa. La interlegibilidad garantiza una entropía hermenéutica que hace leer los textos de un tiempo (y aquellos de la memoria cultural) con una cierta estrechez interpretativa; ella escotomiza la naturaleza heterológica de ciertos escritos, es ciega ante lo inesperado y tiende a reducir lo nuevo a lo previsible. Es en este sentido que las "ideas nuevas" corren el riesgo de pasar desapercibidas, porque son abordadas según los marcos preconstruidos que ofuscan eso que se prestaría aquí y allá a una lectura diferente.

El discurso social "hegemónico" tiene el monopolio de la representación de la realidad, esta representación de la realidad contribuye considerablemente a hacer la realidad -y la historia. Justamente porque es un asunto de monopolio que el discurso social de una época parece adecuado como reflejo de lo real, puesto que "todo el mundo" (salvo algunos malos espíritus) ve lo real y el momento histórico a través de él más o menos de la misma forma. La función de los discursos sociales, función concomitante a sus monopolios de representación, es producir y fijar las credibilidades, las legitimidades, las validaciones, las publicidades (volver públicos los gustos, las opiniones, las informaciones, los valores). De modo complementario, le corresponde rechazar y censurar lo impensable. A la función "monopólica" del discurso social se subordinan las funciones derivadas de la rutinización de la novedad, de convivialidad nacional, de identificación distintiva de grupos y de entornos, de sus gustos y de sus intereses. Lo que llamamos una "cultura" está compuesto 
de contraseñas y de temas convenientes, de temas que llevan a disertar, sobre los cuales hay que informarse y que se ofrecen, no solamente a los "medios", sino también a la literatura y a las ciencias como dignos de meditación y de examen. La hegemonía se presenta aquí como una temática, con saberes vulgares y saberes de gala, con "problemas" preconstruidos, con intereses ligados a objetos cuya existencia y consistencia no parecen plantear dudas, puesto que todo el mundo habla de ellos. Régis Débray lo dice muy bien: "No hay necesidad de adherir a las mismas ideas para respirar el mismo aire. Basta con que acordemos tener esto o aquello por real: lo que es digno de ser debatido. Por medio de esta elección previa, tan espontánea como inconsciente, se despliega lo esencial, a saber, la división entre lo decisivo y lo accesorio"10. Todo debate en la opinión "pública" o en un sector dado, por ásperos que sean los desacuerdos, supone un acuerdo previo basado en el hecho de que el tema "existe", que "merece" ser debatido -y que un denominador común mínimo sirve de primer rango a los desacuerdos y a las polémicas. En este punto tocamos lo que es más perceptible en una coyuntura, aquello que asombra o irrita más al lector de otro país o de otra época: de todos esos "objetos" que nombrábamos, que valorizábamos, que describíamos y comentábamos, cuántos no aparecen como si fuesen tan solo realidades conocibles pero, con el repliegue del tiempo, reducidas al estatus de "bibelots de futilidades sonoras".

El discurso social, así comprendido, es también la ideología en uno de los tantos sentidos asignados a este término borroso y polisémico, esto es el conjunto de la materia ideológica propia de una sociedad dada en un momento dado de su desarrollo. En expresiones del tipo la "ideología louis-philipparde", la "ideología victoriana", etc., el término denota lo que denomino el discurso social global de un estado de sociedad con sus temas recurrentes y sus ideas predominantes, sus valores y sus presupuestos ${ }^{11}$, coexistencia más o menos armoniosa de "ideas" recurrentes que disimula los intereses de la clase dominante para los espíritus simplistas -o que se presenta al menos, a pesar de la división del trabajo simbólico, con tendencias homogeneizadoras que procuran esa suerte de monopolio de representación de la realidad de la que acabo de dar cuenta. Hacemos entonces suya la proposición inaugural de El marxismo y la filosofía del lenguaje ${ }^{12}$ : todo lenguaje es ideológico, todo aquello que significa hace signo en la ideología. Valentin Volosinov enuncia: "El dominio de la ideología coincide con el de los signos: se corresponden mutuamente; ahí donde encontramos el signo, encontramos también la ideología". No es verdad o no tiene ningún sentido decir que enunciados como "¡Francia para los franceses!” o " $\mathrm{iHagan}$ lugar al proletariado consciente y organizado!" sean más ideológicos que "la Marquesa salió a las cinco..." o "el viento remolinante que solapa las persianas / Allí se tuerce el bosque como una cabellera...”13. Ahora bien, ¿qué hemos ganado al extender "ideología" a toda la producción simbólica en su historicidad? Sin duda, hacerse comprender: en los años 1880, La France juive de Drumont es eminentemente "ideológica", pero Las lecciones de los martes del Dr. Charcot dictadas en la Salpétrière y su abordaje de "la sugestión histérica" no lo son menos, aunque de otra manera -y las canciones chauvinistas del café-concert que le dieron fama a Paulus y a Ouvrard, y los apreciados y graves estudios del Señor de Norpois en la Revue des Deux mondes sobre "la cuestión de los Balcanes" lo son seguramente de otra forma, tal y como es, en fin, la no menos ideológica editorial de Jules Guesde en L'Égalité al interpretar la coyuntura a la luz del marxismo (a menos que piense, aunque ya no encontraré mucha gente para pensarlo, que él sólo representa al "socialismo científico"). El sentido universal de la ideología constituye un concepto vacío de sentido, un concepto que se reduce a un principio heurístico que le resulta fecundo. 
26 Mi reflexión sobre el discurso social también debía englobar la recepción, la demanda frente a la oferta, debía evaluar y reconstituir, de manera conjetural, las actitudes y los gustos frente al texto poético de Mallarmé y al de François Coppée, a la propaganda anticlerical de La lanterne o a los panfletos antisemitas de Drumont. En mi libro he hablado del encanto de los géneros y de los discursos. En este punto hay que intentar objetivar la intuición del investigador que trabaja con un cierto repliegue histórico. El sentido literal de los textos que él examina no se le escapa, pero sus encantos se han viciado curiosamente: las "bromas" de los periódicos ya no le hacen reír, mientras que las grandes escenas patéticas del quinto acto de los dramas de éxito lo llevan más bien a sonreír. Las grandes tiradas argumentadas de los doctrinarios, de los pensadores, parecen uniformemente apoyarse sobre argumentos sofísticos, pobres, engañosos. En ellos se aprecia bien la estructura demostrativa, pero los mismos han dejado de convencer. Hay pasajes de novelas que, sabemos, intentaban procurar una impresión de realismo audaz, pero que ya no dejan ver más que su trama ideológica y el artificio de sus procedimientos. En otras palabras, con la distancia de una o dos generaciones, el discurso social tomado en su conjunto ya no funciona, su eficacia dogmática, estética, ética, parece ampliamente viciada. Ante el mencionado repliegue del tiempo, el lector se percibe como una suerte de espíritu maligno, que no está emocionado con eso que supuestamente es patético, no lo seduce lo que se supone libertino, no lo divierte lo que tenía por función entretener. Este lector ve bien que no es en la inmanencia de un texto o de un pasaje donde se puede explicar esta curiosa pérdida de eficacia perlocutoria. El encanto es algo más que la aceptabilidad y las competencias (de producción y de desciframiento) que el texto requiere. El ejemplo de las "bromas" es el más fácil de abordar. El lector de hoy ve bien donde está aquello que hacía reír, pero no se ríe: los presupuestos de esas bromas le parecen demasiado simplonas o muy odiosas, algo bloquea la estimulación cómica, aunque la capacidad de descifrar su lógica no le presenta problemas. El encanto, puede estar en la "repercusión", en el "prestigio", o en la emoción; el encanto de los discursos es inseparable de sus valores éticos, informativos, estéticos, fijados en un momento dado sobre el mercado socio-discursivo. Este valor es a su vez inseparable de la "lectura correcta" requerida por el texto en el momento de su aparición.

Toda investigación válida y prometedora exige una conversión de la mirada, intenta ver cosas evidentes, que ciegan y también cosas realmente escondidas, no siempre por su profundidad, sino a menudo por su expansión, su mutabilidad o su "camaleonismo". Aquí entonces está el principio heurístico que me ha estimulado: pensar históricamente el discurso social, distinguirlo en totalidad y, a la manera de Descartes, "hacer recuentos tan enteros y revisiones tan generales que me dejasen la seguridad de no omitir nada". Percibir el poder de los discursos en su omnipresencia y su omnipotencia, difractado en todo lugar, con sin embargo aquí y allá los disfuncionamientos, los desequilibrios, las brechas que las fuerzas homeostáticas buscan perpetuamente obturar. Formular entonces el principio de una hermenéutica de la totalidad. Todo análisis sectorial -sea de las letras o de las ciencias- se prohíbe distinguir un potencial hermenéutico (por lo tanto, político) global. Me pareció que los caracteres y el sentido del discurso médico sobre la histeria, por ejemplo, no están inter-condicionados ni son inteligibles en su inmanencia. La histeria (el discurso de la escuela de la Salpetrière sobre la histeria) habla además de otra (s) cosa(s) más fuera del desorden neuropatológico, tal y como los discursos de la polisonnerie boulevardière hablan de otras cosas, del Edén prostitucional y de la crónica del demi-monde. Tematizar es poner en conexión un objeto dóxico con otros que ya están allí, 
ya hablados, juzgados, evaluados. Esto es lo que intenté mostrar también en Le cru et le faisandé1 ${ }^{14}$ : no podemos hablar de sexo en 1889, -de "aberraciones sexuales", de "venalidades", de "satisfacciones", del "celo", para evocar el lenguaje de época- a menos que lo hagamos trabajando sobre otros ideologemas que estaban entonces activos: la decadencia de las costumbres, la lascivia judía, los monstruos en sotana, la imperfectibilidad de la raza negra, los estupros campesinos, el anonimato urbano, las degradaciones sociales... "Una" ideología no se vuelve a cerrar jamás sobre ella misma; todo se sostiene, todo se conecta y las configuraciones de sociogramas sugieren recorridos, invitan a explorar sectores dóxicos contiguos, todo análisis exige el dominio subliminal del sistema temático global que forma el discurso social.

He introducido el concepto de migraciones para describir la difusión de ciertos esquemas, de ciertas "ideas", "valores" y de ciertos procedimientos retóricos que van de un género discursivo al otro, de un campo al otro, con la adaptación de estas entidades migratorias a la lógica del campo de llegada y a su herencia de formas propias. Así, lo "médico" en 1889 se encuentra absorbido, integrado y adaptado a las temáticas literarias; los micro-relatos literarios, novelescos sobre todo, son tomados en préstamo por el periodismo o por la escritura científica; los temas de actualidad, al migrar del periodismo hacia sectores más "esotéricos", sufren un avatar, una elevación filosófica, artística o científica.

Un ejemplo sobre el cual he producido un estudio es: "Struggle for life" ${ }^{15}$. En 1889, el ideologema "la lucha por la vida" es un axioma de las ciencias naturales (comprendido de diferentes maneras por las diversas escuelas post-lamarckianas que luchan por comprender la episteme no-teológica de Charles Darwin); entrega un micro-relato enormemente explotado por los géneros novelescos y dramáticos; para el periodismo, deviene un medio de exégesis de la "actualidad". Tiene su variante liberal y su variante socializante. Es polivalente, versátil, bajo la apariencia de la identidad, pero impone también una cierta lógica. No carece, sin embargo, de un contenido mínimo y posee a su vez "átomos con ganchos", es decir, una virtualidad para conectarse con uno u otro ideologema disponible. Desde entonces, puesto que no es un ni simple instrumento que permitiría "pensar lo que queremos", ni una monada de libre combinación, inclina a aquel que lo usa a ciertas conexiones, a ciertas puestas en relación, tiene en una coyuntura dada, una valencia que predetermina en parte el uso que podemos darle. Joubert comparaba los pensamientos con las monedas que circulan en la sociedad, pues pasaban de cerebro en cerebro. El valor de cambio de las imágenes, las ideas y las opiniones prima, en el discurso social, sobre su valor de uso.

He formulado también a contrario la pregunta por la "no contemporaneidad" de ciertos discursos aparentemente concomitantes. Si la hegemonía tiende a volver co-inteligibles o co-aceptables los diferentes discursos predominantes, debe ser posible, sin embargo, localizar, sobre los "márgenes", las prácticas discursivas que aun siendo contemporáneas, son no solamente antagonistas, sino además "incomprensibles" (Leibniz), productos de acciones cognitivas, de "gnoseologías" incompatibles, formaciones discursivas que manifiestan en una coexistencia engañosa la contemporaneidad de lo no contemporáneo. La noción de Ungleichzeitigkeit a la que hago referencia viene de Ernst Bloch y aparece en su ensayo de 1934, Erbschaft dieser Zeit, la aplicaba a lo que percibía de "anacrónico" en las pulsiones pre-capitalistas de las ideologías y "actitudes mentales" de los Nazis: "Todos no están presentes en el mismo tiempo presente, escribía. No están ahí más que exteriormente... Llevan con ellos un pasado que se inmiscuye... Tiempos más antiguos que los de hoy continúan viviendo en capas más antiguas". El discurso clerical-católico de 
fines del siglo XIX, al que consagro un capítulo de 1889, encerrado en la lógica antimodernista del syllabus errorum de Pío IX que consideraba pecaminosa a la prensa, a la literatura y a las ciencias laicas, era un excelente ejemplo del Ungleichzeitgkeit. La glorificación de un retraso mental meticulosamente conservado en este contra-discurso católico, deliberadamente beato, reaccionario, no es no-contemporánea, en el sentido que respondería a una supervivencia (como lo son ciertas "mentalidades" campesinas); representa un "arcaísmo de combate", cuya visión apocalíptica del mundo moderno no se concibe sin interferir en conjunto las angustias de desestabilización simbólica que se expresan un poco en todas partes.

31 Otro placer que me ha procurado el trabajo sobre el discurso social es el hecho de abordar ámbitos vírgenes. Apenas existían algunos trabajos anecdóticos sobre el café-concert; muy pocas monografías sobre la prensa en ese entonces (¿extraño? Sí -era un vestigio propiamente francés, más que alemán o inglés). Casi nada sobre las literaturas "medias" [moyennes] a las que les falta a la vez el prestigio y el encanto de lo vil ${ }^{16}$. Preguntarse sobre lo que hace reír a una sociedad, a través de los "tribunales cómicos", los chistes militares, la prensa satírica, era explorar dominios totalmente desatendidos.

Recurro ahora a un ejemplo, entre otros, de este trabajo exploratorio en "tierras desconocidas". En un extenso estudio, publicado en 1983, me concentro sobre un sector o un género literario no canónico, la novela para damas de fines del siglo XIX. Este trabajo estaba inscrito en un conjunto más vasto, a saber, la topografía general de discursos ad usum forminae de la época, es decir, el conjunto de escritos rotulados para el uso de las mujeres y producidos para su atención. El rápido desarrollo del sector impreso destinado al uso de las mujeres después de 1870, est trae aparejadaratura para "las sos de la instruccio de las mujeres zcamos la versiir ntos de poner en cuestisu lugar"os difereá ligado sobre todo a los progresos de la instrucción. Sin embargo, subsiste un retraso en la alfabetización de las mujeres de clases populares -sin hablar de su solvencia. Lo impreso destinado al sexo femenino -revistas de moda y novelas sentimentales sobre todo-forma así una literatura para "damas", con todo el matiz social que esta palabra comporta. Me hizo falta preguntarme -sin plantear a priori que va de suyo- por qué la novela sentimental, con las finalidades didácticas y moralizantes que trae aparejadas, ocupa un lugar tan considerable en la cosa impresa destinada a las mujeres. De todas formas, lo que importaba era hacer ver de entrada que el "sector" para damas ofrecía también sucedáneos, sean estos embrionarios, de todos los otros discursos legítimos: hay una prensa de actualidad, una filosofía y una ética ("agradables") de las que las revistas de moda ofrecen hermosas muestras; hay incluso una ciencia para las damas, donde los vulgarizadores galantes ofrecen los avatares edulcorados de temas científicos adaptados a las necesidades putativas y a las capacidades intelectuales que se le suponen a las encantadoras lectoras ${ }^{17}$.

En diversos artículos he tenido ocasión de explicar lo que quise hacer y sobre todo corregir, completar, o ilustrar de otras maneras ciertas ideas y ciertas conjeturas que se encuentran en 1889. Hago la síntesis de estos reexámenes y desarrollos posteriores en un ensayo: Théorie $d u$ discours social, notions de topographie discursive et de coupure argumentative. Colloque de Lausanne ${ }^{18}$. También se pueden consultar las actas de un coloquio amistosamente organizado por Yan Hamel sobre el año 1889: $1889 \mathrm{a} \mathrm{eu} \mathrm{vingt} \mathrm{ans:} \mathrm{Questions} \mathrm{à}$ Marc Angenot ${ }^{19}$. 


\section{Fuentes, inspiraciones e influencias} entrecruzamientos de series textuales que constituyen objetos, el de la arqueología del saber, el orden del discurso, el del período que va de Las palabras y las cosas a Vigilar y castigar. Encontramos efectivamente una cuestión primera en Foucault y esta engloba la totalidad de su obra a pesar de los sucesivos cambios de rumbo: ¿de qué manera, a lo largo de la historia, el sujeto humano se ha tomado a sí mismo como objeto de conocimiento? Foucault ha redefinido más tarde su objeto fundamental como una "historia de la verdad" ${ }^{20}$, historia desprovista de entelequias, de teologías, liberada del espectro de la Verdad trascendental. La ha definido como la historización de lo que sucesivamente se ha considerado verdadero, "juegos de lo verdadero y lo falso a través de los cuales el ser se constituye históricamente como experiencia, es decir como algo que puede y debe ser pensado" ${ }^{21}$. En cuanto tal, la obra de Foucault no es una obra militante, sería más bien lo contrario $^{22}$ y no es una obra -felizmente- con la que haya pretendido dar respuesta a todo, pero es una obra que estimula la reflexión, ya sea para incorporarla "traicionándola", ya sea para enmendarla o contradecirla. Abre vías, explora nuevos problemas... Si no es, como decía el otro, "insuperable para nuestro tiempo", sigue siendo al menos fecunda por su audacia, su novedad, sus contradicciones y sus fragilidades.

En un libro de esta época, ¿Creyeron los griegos en sus mitos? ${ }^{23}$, Paul Veyne, historiador de la Antigüedad, amigo y discípulo de Michel Foucault, ha introducido una noción que yo he retomado, la de "programa de verdad". En este libro, el historiador se proponía "estudiar la pluralidad de las modalidades de creencias": cada época desarrolla sus métodos propios para llegar a algo que llama "verdad". De algunos decimos retroactivamente que son absurdos, mitos o ficciones, pero sucede simplemente que ya han dejado de ser nuestros métodos. "Los hombres no encuentran la verdad, la forjan" ${ }^{24}$, concluye Veyne. William James habría estado de acuerdo con esta afirmación.

He sentido una gran admiración por Jean-Pierre Faye, un pensador que se sale de los caminos ya andados y que ha inventado un abordaje propio del análisis de discursos políticos, en su libro Langages totalitaires, posterior a Récit hunique ${ }^{25}$. En mi actual trabajo sobre Fascisme, totalitarisme, religion séculière: trois concepts pour le 20e siècle, vuelvo a encontrar a Faye y a su reciente ensayo Le siècle des idéologies ${ }^{26}$. Trabajar con numerosas muestras, pensaba, debía permitir que se plantearan nuevas preguntas: es algo que había 
hecho Charles Grivel en Production de l'intérêt romanesque (1975): ¿qué cuenta, en el curso de algunos años, la ficción en su conjunto y qué funciones socioculturales desempeña el tópico novelesco?

He tomado del pensamiento de Mikhaïl Bakhtine y de los libros de V. N. Volosinov y P. Medvedev que se le atribuían entonces unánime e indebidamente (esto ya casi no plantea dudas $)^{27}$, la idea de un enfoque intertextual e interdiscursivo generalizado. He hecho mía, como lo he dicho anteriormente, la proposición inaugural de El marxismo y la filosofía del lenguaje: "El dominio de la ideología coincide con el de los signos: ambos se corresponden mutuamente; ahí donde encontramos el signo, encontramos también la ideología". Con todo, veo hoy que eso que retuve del "gran pensador soviético" eran las ideas de Volosinov...

40 En los años que precedieron a mi libro 1889, las lecturas, influencias e inspiraciones que iba recibiendo vinieron en menor medida de la teoría o de la crítica literaria que de la sociología y de la historia cultural e intelectual. Tales eran los tropismos que actuaban sobre mí y tenía todo que aprender en estos dominios. Me compenetré en la problemática de la sociología y la historia cultural con ensayos publicados en Francia desde 1962, como L'Esprit du temps de Edgar Morin, La distinction de Pierre Bourdieu, pasando por los trabajos de Claudre Grignon y Jean-Claude Passeron ${ }^{28}$. La historia cultural, tal como la definía Pascal Ory, estudia "el conjunto de representaciones colectivas, propias de una sociedad (etnia, profesión, nación, corporaciones de oficios, corporaciones de escuelas...), de aquello que las constituye, como de aquello que las instituye". "La historia cultural será entonces la historia social de las representaciones", dicho de otra manera, la historia de representaciones de lo social. "Vasto programa" concedía Pascal Ory ${ }^{29}$. Siendo una historia de las representaciones, desembocaba en la historia de la esfera pública, de la opinión, de las ideas compartidas, de los "mitos" de una sociedad. Puede constatarse con claridad la proximidad de todo esto con la reflexión que yo intentaba llevar a cabo.

Cómo no mencionar a la Escuela de Frankfurt, Th. W. Adorno y sus grandes textos de la preguerra y lo que se había traducido (bastante poco) de Walter Benjamin. También he de mencionar el Anti-Edipo de Gilles Deleuze y Félix Guattari, de donde he tomado el concepto de desterritorialización, así como he retomado el concepto de hegemonía de Antonio Gramsci. Desearía mencionar también el impacto que produjeron en mí los tan novedosos trabajos sobre "la escritura de la historia", pienso en tal sentido en las obras que por entonces se publicaron de Michel de Certeau, Paul Ricoeur y Paul Veyne.

Si tuviese que nombrar un autor que he tenido el vivo deseo de emular - " $\mathrm{Y} Y$ ego! Yo también quiero hacer este tipo de cosas!"- ese sería el israelí Zeev Sternhell, historiador del "prefascismo" en Francia y autor de La droite révolutionnaire, 1855-1914, les origines françaises $d u$ fascisme, publicado por Le Seuil en 1978. Fue este libro, sin duda, el que me llevó a orientarme hacia los años 1880-1890. Lo que se me reveló como algo significativo y profundo fue ese trabajo del historiador de las ideas concebido como un ascenso, trabajo que Sternhell expresa con la metáfora de la larga ruta que el historiador debe recorrer en el sentido inverso del flujo temporal. La idea original por identificar, aquella "que un día se apodera de las masas", es la condición de posibilidad de los acontecimientos y la condición de su inteligibilidad retrospectiva. El argumento clave es que, sin esa preparación intelectual de larga data que desde hace tiempo el historiador de Jerusalén denomina el "prefascismo" en Francia entre 1890 y 1914, el acontecimiento mismo sería inexplicable desde un punto de vista causal: “ $¿ E l$ régimen de la Revolución nacional puede comprenderse de otra manera que no sea como el resultado lógico de la revuelta 
intelectual contra la herencia universalista, individualista, hedonista y laica de las Luces francesas? ¿No es el nacionalismo de la Tierra de los Muertos el que constituye el corazón de la Revolución nacional?" 30

A fuerza de trabajar en pequeños grupos dentro del área de la francofonía, en los mismos sectores emergentes y con las mismas problemáticas colaterales, uno se hace amigos. Mi red de amistades debe mucho a mi trabajo sobre el discurso social y a los encuentros que este ha ocasionado. Ya he evocado anteriormente mis treinta años de colaboración con Régine Robin. El trabajo de investigación recuerda la "soledad de un corredor de fondo" 31 y el investigador lleva una vida autista discutiendo y enfrentándose consigo mismo, pero es agradable encontrarse de vez en cuando con gente con la que hablar y que comprende lo que uno hace.

En Bélgica, los literatos de Lieja habían formado el grupo $\mu$ y habían formulado una original "retórica general". Enseñé su Retórica general, editada por Larousse en 1970. Una larga amistad me vincula a Jacques Dubois. Este se orientó más tarde hacia la sociología de la literatura y de la cultura. Y se dirigió igualmente hacia la novela policiaca. La tesis de Jacques Dubois es que este tipo de novela, considerada "trivial", es la expresión de la modernidad misma ${ }^{32}$. Con Pour Albertine, se ha volcado hacia la "crítica-ficción".

Georges Vignaux trabajaba en Suiza en L'Argumentation: essai d'une logique discursive, que se publicó en Droz en 1976. Aquí también estrechamos lazos de amistad unos años más tarde. Desde sus primeros trabajos de teoría del discurso, Vignaux venía desarrollando conceptos (esquematización, presentación, "micro-mundo") que pretendían enlazar el análisis del discurso con la teoría del conocimiento. Aprecié igualmente su síntesis, poco conocida, Le discours, acteur du monde. Énonciation, argumentation et cognition, Gap: Ophrys, 1988.

Ruth Amossy y Elisheva Roven en Tel Aviv trabajaban entonces en una teoría de los clichés, los lugares comunes, los estereotipos, pero también en el ethos, en la "presentación de sí, en el discurso. Otras amistades. Mi colaboración con Ruth Amossy continúa: soy miembro del comité científico de la revista Argumentation et analyse du discours y en marzo de 2014 iré a dar algunas conferencias a Tel Aviv, a la Cátedra Henri Glasberg de Cultura francesa, en el marco del Programa de retórica del departamento de estudios generales de la Facultad de Letras.

Desde hace más de veinte años mantengo contacto regular en Bruselas con Michel Meyer, el filósofo de la problematología ${ }^{33}$ y pensador de la retórica ${ }^{34}$, al que me une una no menos larga y profunda amistad.

En la misma Montreal pasaban cosas, los grupos se formaban en base a afinidades electivas quizás un poco eclécticas. Profesor en el UQAM, productor de cine en una vida anterior, André Belleau había creado hacia 1982, conmigo y con Antonio Gomez-Moriana, Marie-P. Malcuzinsky y Clive Thomson, el "Círculo Bakhtine" que se reunió asiduamente durante algunos años. Belleau dirigió un número colectivo de la revista Études françaises (vol. 20, n¹, 1984) en el que participamos todos, "Bakhtine, instrucciones de uso". Pero Belleau, a quien yo estaba muy unido, murió en 1986 y el círculo desapareció.

Otra aventura colectiva vuelve a empezar en 1990 (para terminarse rápidamente) cuando se funda en Montreal el Centro interuniversitario de análisis del discurso y de la sociocrítica de textos (CIADEST). Había sido concebido por el hispanista Antonio GomezMoriana, Régine Robin y yo. La UQAM nos había prestado los locales. La creación de este centro se justificaba por la presencia en Montreal y en general en Quebec de un número 
significativo de investigadores que reivindicaban pertenecer a estas corrientes. Los tiempos habían cambiado: la bibliografía -en francés principalmente- de los trabajos de análisis del discurso que publiqué en los cuadernos del centro sumaba alrededor de mil títulos $^{35}$. El CIADEST tuvo una vida activa y atrajo a muchos jóvenes, hasta el día de 1996 que los recortes masivos del gobierno Bouchard terminaron con él.

Ahora podemos retroceder y mirar hacia atrás. La idea de considerar lo que dice una sociedad, lo que en ella es decible y escribible, sus "lugares comunes" y sus "ideas chics", es tan antigua como la modernidad. Una buena parte de los "predecesores" del análisis del discurso social está formada por literatos: a lo largo de toda la modernidad, esa "era de la sospecha", de Flaubert a Léon Bloy, Robert Musil o Nathalie Sarraute, vemos cómo vuelven una y otra vez la enumeración y la interrogación abrumada de las "ideas recibidas", de la "exégesis de los lugares comunes". Ya se trate de Proust (Un Amour de Swann es un episodio que podemos fechar con la presidencia de Jules Grévy o de Sadi Carnot), del Homme sans qualités, o incluso de Fruits d'Or y de Vous les entendez de Sarraute, los novelistas son los que han escuchado y han sabido transcribir con mayor sutileza e ironía el vasto rumor heterológico de los lenguajes sociales.

51 El discurso social está siempre ahí, como mediación, como interposición del colectivo inerte en las relaciones entre los humanos. Es lo que Flaubert ha querido hacer sentir al narrar el reencuentro entre Emma Bovary y Léon en el Albergue de Yonville: la inmersión total de los sentimientos, las sensaciones y los deseos en la alienación de la doxa, del cliché romántico y de las ideas a la moda. Emile Durkheim no sugiere otra cosa cuando escribe: “¿Digan si no es Édouard Drumont o Paul de Cassagnac (dos famosos editorialistas ultra-reaccionarios del fin de siglo, uno antisemita, el otro bonapartista-plebiscitario) los que hablan por la boca de tal buen burgués o de tal excelente sacerdote?" Tanto Emile Durkheim como Tarde estaban fascinados por esa capacidad de los nuevos discursos mediáticos "de impregnar un alma", de tal manera que, decía este último, "el lector habitual deviene el hombre de su periódico".

\section{Seis otros libros justo después}

No es un secreto bien guardado, además todos mis lectores habituales y fieles lo saben: a la obra principal, ahora ya voluminosa, 1889 , un état du discours social, se han sumado seis otros libros que desarrollan otros aspectos y exploran ciertas regiones del llamado "discurso social" en dicha época. Provienen de mi inagotable "escrutinio" de 40.000 fichas ordenadas en cajas de zapatos, en aquellos tiempos inmediatamente anteriores a la generalización del PC:

53 1) Le cru et le faisandé: sexe, discours social et littérature fue el primero en ser publicado, antes de 1889, por las Ediciones Labor de Bruselas, en 1986. El libro trata sobre las tematizaciones y los "saberes" que compiten entre sí sobre la sexualidad, desde el caféconcert y la pequeña prensa libertina hasta el discurso médico, la novela naturalista, etc. Cito sin más el texto de presentación:

Hasta ahora ha habido pocos intentos por describir sistemáticamente la manera en que una sociedad tematiza la sexualidad. ¿Cómo se sitúa el sexo en el discurso, desde el periodismo al derecho, pasando por la medicina y la literatura, desde la pornografía barata a las "audacias" innovadoras de las vanguardias? Le cru et le faisandé examina escritos de todo tipo producidos en Francia y en Bélgica en 1889. Sumerge a la literatura en la totalidad del discurso social del año. Muestra según 
qué tópicos y qué retóricas se producen aquí y allá el saber (y la ansiedad), el sensacionalismo de la prensa, la malicia, la obscenidad, la transgresión.

Desde las aberraciones sexuales del Dr. Garnier a las "pequeñas mujeres" del Correo Francés, desde el Almanaque de Cocottes a las obras de Zola, de Lemonnier, de Rachilde, toda la tipología de géneros del discurso de la Belle Époque y todos los grados de distinción son así recorridos. Nada discrimina tanto las lecturas como la "pornografía", ofreciendo así una imagen de las jerarquías culturales. Lo que adoran unos, repugna a los otros. Tal periodista, asqueado por el inmundo Zola, es totalmente indulgente con el "sano" chiste verde francés...

El autor formula una teoría del discurso social y de las funciones que en él puede tener lo simbólico sexual: por desplazamiento y condensación, el chiste verde o la escena de audacia modernista hacen de la "indecencia" un medio para hablar de otros misterios sociales.

\section{Presses universitaires de Vincennes, 1989 (este trabajo tuvo una continuación más tarde} en Un Juif trahira: le thème de la trahison militaire dans la propagande antisémitique, Montreal, 1995). En este libro estudio, siempre a partir del inagotable trabajo sobre 1889, el desarrollo de la propaganda antisemita en Francia en los años que precedieron al Caso Dreyfus (o, para ser más precisos, en aquellos que precedieron el arresto de Alfred Dreyfus; el Caso como tal no comenzó hasta 1896 o 1897) o busco abordar, más bien, el problema que plantea este aumento del antisemitismo a partir de una problemática diferente a la de otros historiadores. Trabajando a partir de la noción de discurso social y la de topografía (de "división del trabajo" discursivo), buscaba observar no solamente a los "profesionales" del panfleto antisemita -menos aún limitarme a los escritos de quien fuera el más relevante profesional de la cosa, Edouard Drumont- sino identificar y comprender una diseminación general de enunciados recelosos u hostiles con respecto a los Judíos, estereotipos y mitos dispersos en el sistema global de lo que se imprime y se lee en esta época -tanto en la prensa de diversas tendencias, desde clericales hasta socialistas, e incluso, yendo hasta los extremos, desde los carlistas hasta los anarquistas, que encontramos en las grandes revistas "políticas y literarias", los ilustrados, los géneros literarios, las obras científicas, etc...

56 A partir de nuevas y más largas investigaciones, en la segunda obra mencionada, Un Juif trahira, planteo la pregunta de saber cómo, por qué vías y con qué grados de precisión progresiva nace el tema del espionaje militar y de la traición judía en la propaganda antisemita entre 1886 y 1894; cómo, muy precozmente (mucho antes de la campaña "dirigida" lanzada por La libre Parole en 1892) esta sospecha y este objeto de angustia: "un Judío nos espiará, nos traicionará", comenzó a señalar con el dedo a alguien, un artillero quizás, un politécnico, a alguien que tenía cierto apellido, por ejemplo un apellido puesto en la picota de manera recurrente en esta propaganda: el de "Dreyfus" (como lo había mostrado Pierre Birnbaum, cuyas observaciones aún pudimos completar significativamente). Mi objeto de investigación y de reflexión en este segundo estudio era hacer ver exactamente lo que había pasado en el mundo de las representaciones sociales antes de que La libre Parole titulase una buena y, para este periódico, triunfante tarde: "Alta traición. Arresto del oficial judío A. Dreyfus" ${ }^{36}$.

4) Le Café-concert. Archéologie d'une industrie culturelle es un estudio consagrado al caféconcert en Francia a finales del siglo XIX ${ }^{37}$. El material está formado por el conjunto de 
canciones compuestas y publicadas (letra y música) en 1889. En este trabajo busco describir e interpretar el estado de una industria cultural, la primera que presentó todos los rasgos de esa "Kulturindustrie" que ocuparía un lugar hegemónico en el siglo siguiente. Incluso en su etapa paleotécnica, la canción comercial, sin fonógrafo ni radio, crea e impone la lógica de su campo comunicativo (estandarización e inflación de la producción, engendramiento de un público-magma trans-social, estrellato, implantación de una minicultura con su prensa ad hoc y sus fans), asociada a una axiomática de la producción de letras y música.

El café-concert de 1889 permite observar la emergencia de una cultura de masas mediática, cultura cuya evolución posterior no hará más que confirmar las tendencias originales, en una época donde el espectáculo de competición deportiva (a excepción del deporte hípico) y el cine están todavía ausentes, donde la publicidad (impresa o mural) todavía es bastante discreta, y donde las formas modernas del impreso no canónico de ocio -de la astrología periodística a las palabras cruzadas, de la novela policiaca o de espionaje a la prensa de casos policiales sangrientos en primera plana- apenas estaban emergiendo de formas más antiguas: logogrifos y enigmas, $\operatorname{canards}^{38}$, complaintes $^{39}$, prensa a un céntavo, novela por entregas a lo Frédéric Soulié, Suë y Féval. Mi trabajo es el resultado de una búsqueda sistemática sobre las canciones publicadas en 1889, sobre los archivos de la censura, completada por la lectura de toda la prensa del año, y sobre el análisis de los textos de publicistas y de letrados que han escrito sobre el fenómeno, generalmente para deplorarlo. La descripción de un "estado del discurso social" en 1889 ha permitido sumergir al café-concert y sus canciones en el dogma de la época y la totalidad de sus "escribibles", distinguidos y vulgares, letrados y sabios, públicos y esotéricos, que conforman en su intertextualidad el discurso de este tiempo.

5) Tenemos, por fin, un librito sobre la publicidad hacia el cambio de siglo, L'Euvre poétique du Savon du Congo, París: Éditions des Cendres, 1992, que aborda la "mistificación literaria". Desde comienzos de los años 80 hasta la Exposición universal de 1900, aparecía cotidianamente en varios encabezados de la prensa parisina un poema publicitario, un poema diferente cada día alabando el Jabón del Congo. Intenté ver lo que este objeto infinitamente menor podía reflejar del "espíritu" de una época. Seis mil poemas más o menos enviados por rimadores benevolentes y anónimos (¿pero quién puede asegurar que Mallarmé o Verlaine no han mandado sus cuartetos también en alguna ocasión?) en honor a aquel jabón perfumado producido en Roubaix por la Jaboneria Vaissier Frères cuyo propietario era el Sr. Victor Vaissier, un gran aficionado de la publicidad poética.

6) En el transcurso de los años noventa mi reflexión se fue orientando sostenidamente hacia la historia de las ideas políticas y de las ideologías de masa de los siglos XIX y XX, hacia la filosofía política. Me centré así en la historia de las militancias progresistas y de lo que he analizado como "Los Grandes relatos". El primero de los libros que he publicado sobre estos temas de militancias progresistas y de cambio social radical es Topographie $d u$ socialisme français 1889-1890, editado en $1990^{40}$. Trabajando siempre según un corte sincrónico, pero esta vez de dos años, 1889-1890, tomo en consideración todo el material impreso socializante de este período situado en el momento de emergencia de la "sociedad de masas". No he estudiado el movimiento francés (y belga) de entonces, su prensa y sus discursos, como un hecho sincrético, ni como un tipo ideal weberiano, sino que lo he abordado en términos de espacio de enfrentamientos polémicos entre partidos, grupúsculos, revistitas y doctrinas en conflicto, como un círculo cuya periferia está en cualquier sitio y cuyo centro no está en ningún lado, como una "topografía" 
interdiscursiva: tal es el concepto que construyo en esta obra y que nos remite a la problemática que he ido siguiendo a lo largo de los años de múltiples maneras, la de lo conflictivo (sobre un trasfondo hegemónico) en el discurso social o en alguno de sus "campos".

Mi problemática buscaba comprender un fenómeno de una clarísima banalidad dentro de su extrañeza: el mal social es, para todos y cada uno, algo dolorosamente evidente al que tenemos que poder procurarle remedio, encontrar la "solución" y ponernos manos a la obra. Sin embargo, ninguna época, ningún sector de la vida pública y militante nunca ha estado de acuerdo sobre la jerarquía de los problemas, sobre sus causas, y menos aún sobre las soluciones que "se imponen". La crítica del mal social forma así una polémica interminable que es consubstancial al pensamiento político moderno. Se encarna por ejemplo en el partido socialista francés de principios del siglo pasado, la SFIO, "Section Française de l'International Ouvrière", resumiéndose, en sus periódicos y en el transcurso de sus congresos, en una querella inextinguible entre los posibilistas, los partidarios de Jean Jaurès, Jules Guesde, Edouard Vaillant o Jean Allemane, los sindicalistas revolucionarios, los anarco-sindicalistas, los antimilitaristas. Todos ellos tenían una cierta idea del mal que reinaba en la sociedad burguesa capitalista y un remedio para aportar, pero confrontadas unas con otras, estas ideas eran totalmente contradictorias entre sí.

\section{Los Grandes relatos: continuación}

62 Siguiendo a Jean-François Lyotard ${ }^{41}$, llamo "Grandes relatos" a las formaciones ideológicas que se han encargado de procurar a los modernos una hermenéutica histórica al barrer los horizontes del pasado, el presente y el futuro y, al mismo tiempo, de prescribir un remedio definitivo y global a los males que sufre la sociedad (el programa utópico que conllevan constituye la pars construens, como dicen los retóricos, de una edificación demostrativa que parte de una crítica radical de los vicios de la sociedad presente). Los Grandes relatos presentan de hecho una especificidad cognitiva, al estar formados por una secuencia estable y constante de topoï, argumentos y micro-relatos. Se inscriben en un esquema recurrente, indefinidamente reutilizado, al tiempo que despliegan un modo propio de descifrar aquello que va a designarse como "lo social". El largo siglo XIX ha sido el laboratorio de una copiosa invención ideológica ${ }^{42}$-a la que el siglo XX no ha añadido estrictamente nada de substancial-, invención que ha permanecido contenida en un marco de pensamiento específico, en un esquema narrativo y retórico cuyos elementos quedaron fijados a partir del reinado de Louis-Philippe. Esas son las invariantes que he despejado para intentar comprender su papel en la historia y descifrar sus avatares sucesivos.

Desde los reformadores románticos y las primeras sectas socialistas (llamadas posteriormente "utópicas" ${ }^{43}$ ) a las ideologías de masas del siglo XX, y en primer lugar la que se autodenominó "socialismo científico", los dos siglos modernos han asistido al eterno retorno de una forma estructurada de pensamiento militante que va del diagnóstico de males innombrables debidos a "la mala organización de la sociedad", al descubrimiento de su etiología, luego al develamiento de su causa última y a la exposición de un remedio, al descubrimiento de una panacea, conforme a la naturaleza humana y al progreso histórico, y al anuncio demostrativo de la próxima caída de la mala sociedad -a pesar de la vana resistencia de secuaces del mal y enemigos del pueblo- y de la instauración de una sociedad justa, feliz, definitiva e inmutable sobre sus ruinas. 

iban desde la fundación de la Segunda Internacional a la Gran Guerra, he elegido extender aún más mi reflexión en el tiempo, remontando a la crítica social romántica y a los así llamados "socialismos utópicos". De este estudio sobre el conjunto de la modernidad "progresista" salieron cuatro nuevos libros. Pero ya es suficiente. Termino aquí el relato. Ya contaré el resto otra vez, o tal vez nunca.

\section{El lugar y el rol de la literatura}

68 Me parece que el estudio del texto literario carece de interés si se lo aísla de entrada, si se lo corta de la red socio-discursiva en la cual y sobre la cual trabaja. El texto literario está inmerso en el discurso social, sus condiciones de legibilidad nunca son inmanentes. Sin una teoría y una práctica de análisis del discurso social, que es algo distinto y mucho más que la intuición que de él podamos tener, es poco factible abordar el dominio de las letras directamente, sin caer en el a priori, en la intuición incontrolada, en la imputación de funciones interdiscursivas del texto a los caracteres formales del objeto.

69

Tomado del discurso social, producido según los "códigos" sociales, el texto puede ciertamente reproducir la doxa, lo aceptable, lo preconstruido y el prejuicio, pero también puede transgredir, desplazar, confrontar, ironizar, exceder la aceptabilidad establecida. En el primer caso, el texto tiene asegurada una legibilidad inmediata. Por eso mismo, también está destinado a volverse "ilegible" a mediano plazo, a medida que la 
connivencia con la doxa que él expresaba y que lo expresaba se va desvaneciendo. Los textos que problematizan, alteran y desplazan la doxa hegemónica, en cambio, forman parte de aquellos que se inscriben en la indeterminación, lo que los vuelve difícilmente descifrables en lo inmediato, pero les garantiza la posibilidad (más o menos durable) de "otra" legibilidad. Los textos devaluados de las "afueras" de la literatura, los textosmercancía, que en cierta medida escapan a la vigilancia, pueden interesar no solo al crítico de letras sino también al sociólogo y al historiador, en la medida en que es posible analizarlos a la vez como repetición de fórmulas probadas, como estereotipia, como productos de "consumo inmediato", como compulsión para volver a decir lo ya dicho, como pre-juicio y des-conocimiento, pero también como movimiento, resbalones subrepticios, ironía, emergencia de otras lógicas, eventualidad del noch-nicht-Gesagtes, de lo todavía-no-dicho ${ }^{44}$.

Inspirándome en lo que comprendía por entonces del pensamiento de "Bakhtine", así como en los análisis sociocríticos de Claude Duchet, llegué entonces a formular una tesis: que la literatura no conoce sino en segundo grado, que aparece siempre después, en un universo social saturado de palabras, de debates, de los roles lingüísticos y retóricos, de ideologías y de doctrinas que tienen todas, justamente, la pretensión inmanente de servir para algo, de dar a conocer y guiar a los humanos al conferirle sentido (significación y dirección) a sus actos en el mundo. El ser de la literatura, entonces, reside en el trabajo que opera sobre el discurso social, y no en el hecho de que procuraría, a su manera, actas sobre el "mundo" o el "alma", más aún que los periodismos, filosofías, propagandas, doctrinas y ciencias. Hay que concebir a la literatura como un suplemento del discurso social, su tiempo es el de la retrospección, lo que puede convertirla, es cierto, en una aguafiestas.

71 La heteronomía y la heteroglosia no pueden aprehenderse por una intuición local, por el solo examen de aquello que se trama en el campo literario. La heteronomía no es una cualidad intemporal de ciertas obras clasificadas para siempre como disidentes y subversivas, sino que debe aprehenderse en la economía global del discurso social de un momento dado. No puede ser una especie de valor transhistórico. Un lenguaje "otro", la invención de un desvío productivo, la puesta en lenguaje de aporías, todo lo que nos parece constitutivo de los "grandes textos" es en todo momento improbable, no puede explicarse por el simple "talento". El texto literario no se encuentra en una posición realmente dominante; en el fondo, solo opera una ruptura significativa presionado por el advenimiento de una imposibilidad de decir, de la afasia y la asfixia.

El texto literario se inscribe en el discurso social y lo trabaja. Pero el trabajo que opera sobre los discursos sociales no es una tarea transhistórica que va de suyo; ese trabajo es siempre problemático y sus estrategias son múltiples, restringidas, y en una misma sociedad divergentes por sus medios y funciones. El discurso social aparece, visto desde las letras, como un dispositivo problemático, hecho de señuelos, de enigmas, de dilemas y de cuestionamientos. Si los textos, literarios o no, se refieren a lo real, esta referencia se opera en la mediación de lenguajes y de discursos que, en una sociedad dada, "conocen" diferencialmente, e incluso de manera antagónica, un real del cual no se puede decir nada con anterioridad a las diversas maneras en que es conocido ${ }^{45}$.

73 La literatura no se opone a las múltiples actividades discursivas que dividen el trabajo en la topografía cultural por el hecho de que en su espacio o en su "Torre de marfil" se libraría al vano y gratuito trabajo de deconstruir sentidos y estaría gloriosamente privada, ella sola, de finalidad práctica y de télos. Precisamente, la literatura no está sola 
en una esquina, ni "fuera de su siglo", ya se trate de la novela realista o modernista, o de poesía cubista o surrealista: la literatura es ese discurso que, presente en el mundo, viene a tomar la palabra y a trabajar con "las palabras de la tribu", después de que todos los otros discursos han dicho lo que tenían que decir, y especialmente los discursos de certeza y de identidad. Parece tener el mandato de escucharlos, para repercutir sus ecos e interrogarlos a través de su confrontación mutua. Por el sólo hecho de que viene después, no va a remendar las positividades cívicas, agregar la funcionalidad práctica, la certeza imperativa, porque, precisamente, todo esto existe abundantemente en el resto del discurso social, unas certezas que, tejidas todas de contradicciones, presentan un antagonismo mutuo declarado o larvado. El texto novelesco moderno, por ejemplo, es entonces un dispositivo de collages, de efectos dialógicos, de ambigüedades semánticas, de polisemia y de polifonía, no por algún tipo de manía formal o por sumisión a una evolución estética trascendente, sino precisamente porque -incluso en la novela más chata, más de tesis- no hace más que reflejar y registrar el rumor cacofónico del discurso social global con sus voces discordantes, sus legitimidades indecidibles, sus ecos y sus parodias, y escucha con certeza, al encontrarse a la distancia justa, las diferentes tematizaciones concurrentes de las mismas cosas, lo que murmura y lo que retumba.

La literatura no sabe hacer más que esto: contar en segundo grado esa cacofonía interdiscursiva, llena de desviaciones y de deslizamientos de sentido y de aporías más o menos hábilmente tapadas. Solo puede manifestar aquello que se disimula bajo la lógica aparente del discurso social (de los discursos sociales), es decir, la incapacidad ontológica en la que este se encuentra de conocer el mundo y el curso de la historia de manera estable y coherente, sin enfrentamientos irreductibles entre las "visiones del mundo" que lo habitan, sin "vicios escondidos" en los sistemas y las explicaciones, y sin exponerse de repente al desventurado encuentro con lo real.

Mis libros sobre el discurso social, en análisis del discurso e historia de las ideas

- Les Champions des femmes. Examen du discours sur la supériorité des femmes, 1400-1800, Montreal:

Presses de l'Université du Québec, 1977, 194 p.

- La Parole pamphlétaire, contribution à la typologie des discours modernes, París: Payot 1982, 416 p.

Colección "Langages et sociétés" dirigida por Louis-Jean Calvet.

- Le Cru et le faisandé: sexe, discours social et littérature à la Belle Époque, Bruselas: Labor, 1986, 202 p.

Colección “Archives du futur” bajo el auspicio de Archivos y Museo de la literatura.

- Ce que l'on dit des Juifs en 1889. Antisémitisme et discours social, Prefacio de Madeleine Rebérioux, Saint-Denis: PUV, 1989, 192 p. Colección “Culture et Société".

- Mil huit cent quatre-vingt-neuf: un état du discours social, Longueuil: Préambule, 1989, 1176 p. Colección "L'Univers des discours" dirigida por Antonio Gomez-Moriana y Danielle Trottier.

- Le Centenaire de la Révolution, París: La Documentation française, 1989, XVI planches hors-texte, $64 \mathrm{p}$.

- Topographie du socialisme français, 1889-1890, Montreal: Discours social, 1990, 210 p. Colección

“Discours social-Monographies". $2^{2}$ edición Montreal: Discours social, 2006, 347 p. Colección

"Discours social", XXV.

- Con la colaboración de Diane Geoffrion, Le café-concert, archéologie d'une industrie culturelle, Montreal: CIADEST, 1991, 114 p. Colección “Cahiers de recherche”, VII. 
- "Un Juif trahira": l'espionnage militaire dans la propagande antisémitique 1886-1894, Montreal: CIADEST, 1994. 132 p. Colección “Cahiers de recherche”, XVIII. Reedición de este cuaderno agotado, con correcciones menores, bajo el título "Un Juif trahira". Le thème de l'espionnage militaire dans la propagande antisémitique, 1886-1894, Montreal: Discours social, 2003, 117 p.

- L'Utopie collectiviste: le Grand récit socialiste sous la Deuxième Internationale, París: PUF, 1993, 400 p. Colección "Pratiques théoriques" dirigida por Étienne Balibar y Dominique Lecourt.

- Les Idéologies du ressentiment, Montreal: XYZ, 1995, 174 p. Colección “Documents” dirigida por Gaëtan Lévesque.

- La Propagande socialiste. Six essais d'analyse du discours, Montreal: Balzac/Le Griot, 1997, 365 p. Colección "L'Univers des discours" dirigida por Antonio Gomez-Moriana y Walter Moser.

- Interdiscursividades. De hegemonias y disidencias, Traducido por María Teresa Dalmasso, Cordoba: Universidad nacional de Córdoba, 1998, 219 p. Colección “Conexiones y Estilos”, dirigida por Antonio Oviedo. Obra reeditada en 2010.

- Colins et le socialisme rationnel, Montreal: PUM, 1999, 192 p.

- La critique au service de la Révolution, Lovaina y Paris: Vrin, 2000, 442p. Colección “Accent" dirigida por Jan Baetens, Dirk De Schutter y Koen Geldof.

- Les Grands récits militants des XIXe et XXe siècles: religions de l'humanité et sciences de l'histoire, París: L'Harmattan, 2000, 222 p. Colección "L'Ouverture philosophique" dirigida por Dominique Château y Bruno Péquignot.

- L'ennemi du peuple. Représentation du bourgeois dans le discours socialiste, 1830-1917. Montreal: Discours social, 2001, 142 p. Colección “Discours social”, IV.

- D'où venons-nous, où allons-nous? La décomposition de l'idée de progrès, Montreal: Trait d'Union, 2001, 180 p. Colección "Spirale" dirigida por Pierre Ouellet.

- L'antimilitarisme: idéologie et utopie, Quebec: Presses de l'Université Laval, 2003, 143 p. Colección "Minerve du Nord" dirigida por Josiane Boulad-Ayoub.

- Interventions critiques I: Analyse du discours, rhétorique, théorie du discours social, Montreal: Discours social, Nouvelle série/New Series, Volume VIII, 2002, 292 p.

- Anarchistes et socialistes: trente-cinq ans de dialogue de sourds, Montreal: Discours social, Nouvelle série/New Series, Volume XIV, 2003, 77 p. Estudio integralmente retomado en la obra colectiva de Michel Murat, Jacqueline Dangel y Gilles De Clercq (dir.), La Parole polémique, París: Champion, 2003, pp. 449-513.

- La démocratie, c'est le mal. Un siècle d'argumentation anti-démocratique à l'extrême gauche, 1815-1914, Quebec: Presses de l'Université Laval, 2004, 182 p. Colección “Minerve du Nord”, dirigida por Josiane Boulad-Ayoub.

- Rhétorique de l'anti-socialisme. Essai d'histoire discursive, 1830-1914, Quebec: Presses de l'Université Laval, 2004, $274 \mathrm{p}$.

- Le marxisme dans les Grands récits. Essai d'analyse du discours, París: L 'Harmattan y Quebec: Presses de l'Université Laval, 2005, 466 p.

- Religions séculières: pour l'histoire d'un concept. Seguido de: Synthèses du XXe siècle. Deux essais bibliographiques, Montreal: Discours social, 2004, 147 p. Colección "Discours social”, XX. Puesto al día y en línea en 2007, bajo el nuevo título Religions séculières, totalitarisme, fascisme: des concepts pour le XXe siècle. Seguido de: Le Mal: mal moral, mal politique, mal social - Les intellectuels, Les 
intellectuels de parti, Intellectuels et rôle politique - Synthèses du vingtième siècle. Bibliografías razonadas precedidas de Comentarios sobre "religiones seculares" y "totalitarismo", 226p.

- Tombeau d'Auguste Comte, Montreal: Discours social, 2006, 109 p. Colección “Discours social”, Nouvelle série, XXVI.

- Théorie du discours social. Notions de topographie des discours et de coupures cognitives, Montréal: Discours social, 2006, 54 p. Colección "Discours social”, Nouvelle série, XXVII.

- Dialogues de sourds. Traité de rhétorique antilogique, París: Mille et une Nuits, 2008, 455 p. El tratado aparece primero en una versión algo más larga acompañada de un volumen anexo de bibliografía: Dialogues de sourds. Traité de rhétorique antilogique, Montreal: Discours social, 2006, 2 volúmenes de 535 p. 78 p.

- Vivre dans l'histoire au 20e siècle. Mémoires, déchiffrements, mandats, craintes et espérances. Esquisse d'une histoire subjective, Montréal: Discours social, 2008, 220 p.

- Gnose et millénarisme, deux concepts pour le 20e siècle. Seguido de Modernité et sécularisation, Montreal: Discours social, 2008, $382 \mathrm{p}$.

- En quoi sommes-nous encore pieux? Sur l'état présent des croyances en Occident. Seguido de Réplique de l'avocat du diable par Georges A. Lebel, Quebec: Presses de l'Université Laval, 2009.

- L'immunité de la France envers le fascisme: un demi-siècle de polémiques historiennes. Seguido de: Le fascisme dans tous les pays, Montreal: Discours social, 2009, 205 p.

- Dialogue entre Laurence Guellec et Marc Angenot. Rhétorique, théorie du discours social, histoire des idées, dix-neuvième siècle, Montreal: Discours social, 2010, 77 p.

- "Rupture avec le capitalisme". Le discours socialiste français, 1971-1981: contexte historique, croyance et décroyance, notes pour le colloque “Amnésies françaises", Lille III, mayo 2010, Montreal: Discours social, 2010.

- El discurso social. Los limites históricos de lo pensable y lo decible, Buenos Aires: Siglo XXI, 2010, 228 p. Colección de textos en español precedido de un «Prefacio» inédito del autor. "Presentación" de María Teresa Dalmasso

- L'histoire des idées : problématiques, objets, concepts, enjeux, débats, méthodes, Montreal: Discours social, 2011, 2 volúmenes.

- Le rationnel et le raisonnable. Sur un distinguo de Chaïm Perelman, Montreal: Discours social, vol. XLII, 2012, $158 \mathrm{p} 42^{46}$.

- Rhétorique de la confiance et de l'autorité, Montreal: Discours social, vol. 44, 2013.

\section{NOTAS}

1. En 2001 fui designado para un cargo de investigación, el James McGill Professorship de estudio del discurso social.

2. Consejo de Investigaciones en Ciencias Humanas de Canadá. Constituido por ley del Parlamento en 1977. 
3. Sin embargo, es posible señalar que los primeros trabajos eruditos sobre Trivialliteratur remontan, en lengua alemana, a principios del siglo pasado. En francés, el trabajo universitario más antiguo que conserva un interés real y aborda un género no canónico, es la tesis de Régis Messac (¡profesor en la Universidad McGill hacia 1920!) sobre la novela policiaca, Le "Detective Novel" et l'influence de la pensée scientifique, incluida en la Biblioteca de literatura comparada de Fernand Baldensperger. Hice el prefacio de su novela en clave sobre la Universidad McGill, recientemente reeditada: Régis Messac, Smith Conundrum: Roman d'une université américaine, París: Ex Nihilo, 2010.

4. En coautoría con Lucie Olbrechts-Tyteca, Traité de l'argumentation. La Nouvelle rhétorique, París: PUF, 1958, 2 vol. Reeditado en edición de bolsillo en Bruselas: ULB, 1988. En 2012 publiqué un pequeño ensayo en Cahiers du Discours social sobre el pensamiento filosófico, jurídico y retórico de Perelman: Le rationnel et le raisonnable. Sur un distinguo de Chaïm Perelman.

5. Ver mi ensayo sobre su obra: "Régine Robin à ses débuts, ou: L'invention de l'analyse du discours", Caroline Désy et al. (dir.), Une Euvre indisciplinaire: Mémoire, texte et identité chez Régine Robin, Quebec: Presses de l'Université Laval, 2007, pp. 13-22.

6. Valérie nació en marzo de 1972. Ella es egiptóloga. Maya es abogada.

7. El estudio que publiqué sobre ello me distrajo hasta llegar a producir: "Le Drame de Meyerling: production narrative, acceptabilité et discours social”, Walter Moser y François Latraverse (dir.), Vienne au tournant du siècle, Montreal: Albin-Michel, 1988, pp. 67-90. También se puede consultar mi análisis paralelo del asunto de Meyerling y de Disciple de Paul Bourget: "On est toujours le disciple de quelqu'un, ou: le Mystère du pousse-au-crime", Uri Eisenzweig (dir.), "Le Roman policier", Littérature ( ${ }^{\circ} 49$, février 1983, pp. 50-62).

8. Donde enseñé en la EHESS de la Vieille Charité, invitado por J.-C. Passeron en 1985.

9. Editor al que Antonio Gomez-Moriana había convencido de recibir su nueva colección -El Universo de Discursos- que, por cierto, tiene algunos títulos remarcables. Algunos años más tarde, Le Préambule, rebautizado Éditions Balzac, pondrá la llave sobre su puerta.

10. Régis Debray, L'Emprise, París: Le Débat-Gallimard, 2000, p. 82.

11. No encontramos esto más que en raros trabajos -y no en francés- consagrados a la reconstrucción del "espíritu" de una época a través de la hegemonía de ciertas ideas e "imágenes" dominantes (y no a través de sus costumbres y sus instituciones o más bien rechazándolas en un segundo plano): la visión del mundo isabelino ha sido reconstituida por Eustace Tillyard, la de los colonos de la Nueva Inglaterra en el siglo XVII por Perry Miller.

12. Obra por entonces atribuida a Bakhtine.

13. Versos de Albert Samain.

14. Bruselas: Labor, 1986.

15. "La lutte pour la vie: usages et migrations d'un idéologème", Giuseppe Di Stefano y Russell McGillivray (dir.), La Locution. Actes du colloque international de Montréal, Montreal: Cérès, 1986.

16. Por ejemplo André Theuriet y Victor Cherbuliez, novelistas académicos y mundanos tenidos por indigentes según el "circuito restringido". ¿Qué hacer con los especialistas de "géneros menores" que pululan de acuerdo a la demanda inextinguible y creciente del Periódico, con Armand Silvestre, poeta de músicas de salón y contador de chistes verdes; con Jules Moineaux (padre de Courteline), cuentista y guionista de los "tribunales cómicos" y de los chistes militares, y con cientos más que ocupan una "franja horaria" menor, bien lejos del Canon, pero no en los tenebrosos exteriores de la Indignidad estética?

17. "Des romans pour les femmes: un secteur du discours social en 1889", L'Effet sentimental, número presentado por Caroline Barrett, Études littéraires, Quebec, vol. 3, 1983, pp. 317-350.

18. Vol. 27, Montreal: Discours social, 2006. Se encuentra también in extenso en la recopilación "Discours en contextes", de la revista Contextes, $\mathrm{n}^{\circ}$ 1, 2006. En línea: http:// contextes.revues.org/51?\&id $=51$. 
19. Bajo la dirección de Yan Hamel y Emmanuelle Jacques, vol. 36, Montreal: Discours social, primavera 2010.

20. Histoire de la sexualité, L'usage des plaisirs, vol. II., París: Gallimard, 1984, p. 12.

21. Ibíd.

22. Lo que no quiere decir que Foucault no haya militado activamente, "en su vida", por ciertas causas, contra la prisión, por la liberación gay -era su derecho, claro. Pero su obra "escéptica" no funda tales activismos... no más que cualquier otra.

23. Les Grecs ont-ils cru à leur mythe?, París: Le Seuil, 1983.

24. Op. cit., p.12. La pregunta que se hacía Veyne no es "arqueológica" y no hay necesidad de volver muy atrás en el tiempo para encontrarla. Desde que el historiador del movimiento socialista en el que me he convertido se pregunta, transponiendo los términos: si acaso Jean Jaurés o Karl Kausky o Émile Vandervelde antes de 1914 han "creído en su mito" al cual han contribuido con centenas de folletos y de discursos, a saber, en la sociabilización de los medios de producción, remedio para todos los males de la sociedad, aportada por una pacífica revolución del proletariado inminente y conducente a una jubilosa Democracia del trabajo, ustedes se enfrentan a dificultades que no es ocioso plantearse. Cuanto menos es imposible dar con una respuesta univoca y simple.

25. [El título de Jean-Pierre Faye realiza un juego de palabras entre "unique" (único) y "hunnique" (relativos a los hunos). Ambos términos son homofónicos, lo que genera una palabra nido con una aparente falta de ortografía. En castellano se mantiene este juego de palabras].

26. París: Armand Colin, 1996.

27. Bakhtine démasqué: Histoire d'un menteur, d'une escroquerie et d'un délire collectif es un ensayo publicado en Droz por Jean-Paul Bronckart y Cristian Bota en 2011. Pone en cuestión el origen de varias ideas atribuidas a Mikhaïl Bakhtine y su coherencia en el seno de su obra, y retrata una prolífica y rentable Bakhtin Industry que ha operado una "composición fundamentalmente heterogénea de plagios", de nominaciones y de falsas atribuciones. Bronckart y Bota se aplican para distinguir las voces de Pavel Medvedev, Valentin Volochinov y Bakhtine de los escritos de Bakhtine: este último tenía perspectivas políticas y filosóficas totalmente opuestas a aquellas de los dos teóricos marxistas desaparecidos en los años ‘30. Las obras más importantes incriminadas son El marxismo y la filosofía del lenguaje de Volochinov y El método formal en los estudios literarios de Medvedev. Ahora bien, se trata de las obras que fueron atribuidas entonces a Bakhtine (tras la declaración del lingüista Vjaceslav Ivanov según la cual estos textos habían sido manifiestamente escritos por Bakhtine) y que había que devolvérselas a sus autores que, además, habían retenido mucho mi atención.

28. Claude Grignon y Jean-Claude Passeron, Le savant et le populaire. Misérabilisme et populisme en sociologie et en littérature, París: Gallimard y Le Seuil, 1989. Véase también un volumen colectivo anterior: À propos des cultures populaires, Marseille: CERCOM, 1985.

29. L'Entre-deux-mai. Histoire culturelle de la France 1968-1981, París: Le Seuil, 1983, p. 7. Ver también del mismo autor La culture comme ouverture, treize exercices d'histoire culturelle, París: Complexe, 2008; y de Roger Chartier, “Le monde comme représentation", Annales, vol. 44, nº 6, 1989, pp. 1505-1520.

30. Ni droite ni gauche, p. 50.

31. [Alusión a la película inglesa La soledad de un corredor de fondo (1962), del director Tony Richard, basada en el cuento "The loneliness of de Long Distance Runner" (1959) de Allan Sillitoe].

32. Le roman policier, ou la modernité, París: Nathan, 1992. Citaré también el libro de Uri Eisenzweig, Le Récit impossible, París: Christian Bourgois. 
33. Me refiero aquí a los grandes libros de Michel Meyer entre los cuales figura De la problématologie: langage, science et philosophie, Bruselas: Mardaga, 1986. Meyer es el presidente del Centro Europeo para el estudio de la argumentación y el director de la Revista Internacional de Filosofía.

34. Ver sus Principia Rhetórica. Une théorie générale de l'argumentation, París: Fayard, 2008.

35. L'Analyse du discours, bibliographie de travail, indexado por Chung Ook, Montreal: CIADEST, 1992.

36. La libre Parole, $1^{\circ}$ de noviembre de 1894, p. 1.

37. Con la colaboración de Diane Geoffrion; Montreal: CIADEST, 1991.

38. [Desde el siglo XVI se publicaban en Francia los canards. Pequeños boletines de información, a menudo anónimos, estaban dedicados a la publicación de casos policiales particularmente sanguinarios o aterradores, tenían un carácter sensacionalista y estaban dirigidos a un público popular].

39. [La complainte fue durante los siglos XVIII y XIX un tipo de canción popular que narraba hechos trágicos o crímenes célebres].

40. Reeditado en 2006 en la colección Discours social. Veremos también un poco más tarde, la recopilación de artículos sobre diversos temas y aspectos de la propaganda de principios de la Segunda Internacional: La Propagande socialiste: six essais d'analyse du discours, Montreal: Balzac, 1997.

41. La condition postmoderne. Rapport sur le savoir, París: Minuit, 1979.

42. Incluyendo esas transposiciones paródicas en clave reaccionaria, liturgias de masa y cultos de jefe incluidos, que son las ideologías fascistas. Ahí donde los socialistas "científicos", enredados de escrúpulos racionalistas, no querían explotar conscientemente y a fondo el potente carácter gnóstico-milenarista de sus doctrinas, ni utilizar cínicamente el fanatismo que ellas podían inspirar con sus textos sagrados, su bandera roja, sus cultos y liturgias, los fascistas, penetrados de la filosofía vitalista de Lebens, van a ir a robar desvergonzados este potencial del adversario al poner al servicio de un "mito" que a sus ojos (sin duda tenían razón sobre este punto) es más potente que la lucha de clases -el de la Nación y de su "renacimiento", de la "Palingenesia nacional".

43. Aunque los fourieristas y los sansimonianos hablaban todos ya, mucho antes que el "socialismo científico" bautizado por Engels en 1877 para poner en valor el trabajo de su amigo Marx, de una "ciencia social" nuevamente descubierta por su Maestro...

44. He desarrollado esta reflexión en particular en "Que peut la littérature? Sociocritique et critique du discours social”, Marie-Claire Ropars y Jacques Neefs (dir.), La Politique du texte: enjeux sociocritiques. Pour Claude Duchet, Lille: PUL, 1992, pp. 9-27. En línea: http:// sociocritique.mcgill.ca/Pdf/Angenot3.pdf

45. Vuelvo aquí a mi artículo con Régine Robin, "L'Inscription du discours social", Sociocriticism, I, $\mathrm{n}^{\circ} 2,1985$.

46. Antepenúltimo volumen aparecido en abril de 2012: un colectivo que he dirigido, Rhétorique des controverses savantes et des polémiques publiques, forma el volumen XLIII de "Discours social". Trabajo desde hace varios meses (o más bien años) en un estudio de historia conceptual en cuatro volúmenes, que pienso terminar en 2013-14 y que aparecerá en pre-publicación en el Discurso Social, formando los volúmenes 37, 38, 39 y 40 de la colección: Fascisme, totalitarisme, religion séculière: trois concepts pour le 20e siècle (el volumen 37 está en dos partes: "Catégories historiques et idéaltypes - Fascisme"; el primero aparecerá a fines de 2013. El volumen 40 incluirá los anexos: "Religion, sacré, dogme, croyance" y "Religion civile"). 


\section{AUTORES}

MARC ANGENOT

McGill University 